\title{
The Presence and Prevalence of Bovine Parainfluenza 3 (BPIV-3), Bovine Papillomaviruses (BPV), Bovine Herpesvirus 1 (BHV-1) in Subclinical Mastitis in Cattle
}

\author{
Serdar ALTUN*1, Selçuk ÖZDEMİR ${ }^{2}$, Yavuz Selim SAĞLAM ${ }^{1}$ \\ 1 Atatürk University, Faculty of Veterinary Medicine, Department of Pathology. Erzurum-Turkey \\ 2 Atatürk University, Faculty of Veterinary Medicine, Department of Genetics. Erzurum-Turkey
}

\begin{abstract}
In general, bacterial pathogens are the focus of mastitis studies. Symptoms of mastitis may be absent in cases of viral infection, because other clinical symptoms are more dominant. Subclinical mastitis cases cannot be generally diagnosed and as a consequence, they are not investigated very well. This may lead to the inability of viral agents to be predicted in bovine subclinical cases. There are many viral agents associated with bovine mastitis and which may cause subclinical mastitis in dairy cattle. However, since viral infections have not been much investigated in mastitis studies, strategies developed against subclinical mastitis may be inadequate. Bovine Parainfluenza 3 (BPIV-3), Bovine Papillomaviruses (BPV), Bovine Herpesvirus 1 (BHV-1) could cause clinical and subclinical mastitis. The aim of the present study was to investigate the presence and prevalence of BPIV-3, BPV, and BHV-1 viral agents in subclinical mastitis case in Erzurum province. For this purpose, 120 bovine mammary tissues with no macroscopic lesions were collected and these tissues were examined with histopathology and immunofluorescence methods. Thereafter, all viruses were identified with qRT-PCR in mammary tissues. The end of histopathologic process 78 of 120 cases (56 chronic subclinic mastitis, 22 acut mastitis) was found severity of inflammatory changes. According to the results of immunofluorescence staining for all sections. The immun positive signs for BPIV-3 BPV, and BHV-1 was determined in 50 out of 120 cases. qRT-PCR results which compatible with immunofluorescence results showed that BPIV-3 agent was detected by the qRT-PCR in 26/120 samples, BPV-2 agent in 8/120 samples, BHV-1 agent in 16/120 samples, and BPV-1 agent in 7/120 samples (only by qRT-PCR). Coinfection with BPIV-3 and BHV-1 was detected in 5/120 samples, BPIV-3, and BPV-1 in 3/120 samples, BHV-1, and BPV-2 in 2/120 samples. According to our results, although the role of viral agents in mastitis disease has not been clearly elucidated, we have found that viral agents are common in mammary tissues with subclinical mastitis.
\end{abstract}

Keywords: Subclinical mastit, Bovine Parainfluenza 3, Bovine Papillomaviruses, Bovine Herpesvirus 1, qRT-PCR, Immunofluorescence.

\section{Sığırlarda Subklinik Mastitisde Sığır Parainfluenza 3 (BPIV-3), Sığır Papillomavirüsleri (BPV), Sığır Herpesvirüs 1 (BHV-1) Varlı̆̆1 ve Prevalans1}

\section{ÖZ}

Genellikle etiyolojik mastitis çalısmaları bakteriyel patojenler üzerine odaklanmıştır. Viral enfeksiyon vakalarında mastit belirtileri, diğer klinik semptomlar daha baskın olduğu için gözden kaçabilmektedir. Subklinik mastitis olguları genellikle teşhis edilemediği için çok iyi araştırılmamıştır. Bu durum sığır subklinik mastitis vakalarında viral ajanların önlenememesine yol açabilmektedir. Sığırlarda mastitis ile ilişkili ve süt sığırlarında subklinik mastite neden olabilecek birçok viral ajan tanımlanmıştır. Bununla birlikte, mastitis çalışmalarında viral enfeksiyonlar çok fazla araştırılmamış olduğundan, subklinik mastitislere karşı geliştirilen stratejiler yetersiz olabilir. Sığır Parainfluenza 3 (BPIV-3), Sığır papillomavirüsleri (BPV), sığır herpes virüsü 1 (BHV-1) klinik ve subklinik mastitlerde rol aldığı düşünülen viral ajanlardır. Bu çalışmada, Erzurum ilindeki subklinik mastitis olgularındaki BPIV-3, BPV ve BHV-1 viral ajanlarının varlığının ve prevalansının araştırılması amaçlanmıştır. Bu amaçla 120 büyükbaş hayvanın makroskobik olarak lezyon izlenmyen meme doku örnekleri toplandı ve bu dokular histopatoloji ve immünofloresan yöntemlerle incelendi. Ayrıca, meme dokularında belirlenen viral etkenlerin varlığ $\mathrm{qRT}$-PCR ile araştırıldı. Toplanan 120 örneğe yapılan histopatolojik değerlendirme sonucunda (56 kronik mastit, 22 akut mastit) 78 örnekte yangisal değişikliklere rastlandı. Tüm dokulara uygulanan immünofloresan boyama sonuçlarına göre 120 olguda kronik mastitis tanısı konan 50 örnekte pozitif reaksiyonlara rastlandı. qRT-PCR sonuçlarına göre immunfloresan boyama sonuçlarıla uyumlu olarak toplam 50 (\%41.6) örnekte etkenlerin DNA varlıkları tespit edildi. BPIV-3 etkenine 26/120, BPV-2 etkenine 8/120, BHV-1 etkenine 16/120 oranında olduğ tespit edildi. Sadece qRT-PCR yöntemi kullanılarak 7/120 oranında BPV-1 etkenine rastlandı. Ayrıca, 5/120 oranında BPIV3 ve BHV-1, 3/120 oranında BPIV-3 ve BPV-1, 2/120 oranında ise BHV-1 ve BPV-2 etkenlerine birlikte rastlandı. Yapılan çalışmadan elde edilen sonuçlara göre, mastitis hastalı̆̆ında viral ajanların rolü açık bir şekilde aydınlatılmamış olmakla birlikte, viral ajanların subklinik mastitli meme dokularında yaygın olduğunu tespit edilmiştir.

Anahtar Kelimeler: Subklinik mastitis, Sığır Parainfluenza 3, Sığır Papillomavirüsleri, Sığır Herpes virüsü 1, qRT-PCR, İmmünofloresan.

To cite this article: Altun S. Özdemir S. Sağlam Y.S. The Presence and Prevalence of Bovine Parainfluenza 3 (BPIV-3), Bovine Papillomaviruses (BPV), Bovine Herpesvirus 1 (BHV-1) in Subclinical Mastitis in Cattle. Kocatepe Vet J. (2019) 12(2):135-143

Submission: 02.11.2018 Accepted: 25.03.2019 Published Online: 15.05 .2019

ORCID ID; SA: 0000-0002-8735-7031, SÖ: 0000-0001-7539-0523, YSS: 0000-0002-7861-9642

*Corresponding author e-mail: serdar.altun@atauni.edu.tr 


\section{INTRODUCTION}

Mastitis is defined as an inflammatory response resulting in the infection of mammary tissue. Mastitis has been reported to occur in many mammals, especially in dairy cattle (Gomes and Henriques 2016). Mastitis in domestic dairy cattle causes economic losses. The economic problems caused by mastitis is related to direct and indirect losses. Direct losses are due to treatment costs, unaccountable milk, staff costs, deaths, and recurrence of mastitis. Indirect losses are caused by lower milk yield, lower milk quality, increased separation, decreased animal welfare and other health problems (Petrovski et al. 2006). The great majority of mastitis cases are bacterial and nonbacterial infections such as mycoplasms, fungi, yeasts, virus, and chlamydia (Wellenberg et al. 2002). Mastitis is divided into clinical and subclinical form. In clinical mastitis, the risk of contamination can be stopped to separate the animal from the herd, but the subclinical mastitis continues to flock because the animal does not show clinical symptoms, and mastitis causes the other animals to catch up. As a result, the economic losses is getting bigger (Bogni et al. 2011).

Although the bacterial pathogens are the focus of mastitis studies. There are many viral agents associated with bovine mastitis and which may cause or play important role in subclinical mastitis in dairy cattle (Wellenberg et al. 2002, Kalman et al. 2004). However, since viral infections have not been much investigated in mastitis studies, strategies developed against subclinical mastitis may be inadequate.

Bovine Herpesvirus (BHV-1) (Hage JJ et al. 1998), Bovine Parainfluenza 3 (BPIV-3) virus (Kawakami et al. 1966a,b), Bovine Papillomaviruses (Wellenberg et al. 2002) could cause or play a role in clinical and subclinical mastitis. BHV-1, a member of the Herpesviridae family, can lead to serious diseases such as infectious bovine rhinotracheitis (IBR), infectious pustular vulvovaginitis (IPV) and infectious pustular balanoposthitis. Diseases caused by the virus include conjunctivitis, rhinotracheitis, abortion, encephalomyelitis, and mastitis (Underwood et al. 2015). Roberts et al. (1974) isolated BHV-1 from a cattle with mastitis in the USA. In addition, BHV-1 was identified in bovine milk with mastitis in combination with Mycoplasma species (Espinasse et al. 1974, Gourlay et al. 1974). Bilge (1998) reported that BHV-1 was found in one of the milk samples obtained from 96 cows with mastitis. BHV-1 leads to high milk cell counts even if there is no other pathogens that cause the mastitis (Siegler et al., 1984). In addition, it may cause the mastitis when the udder was infected with BHV1, and was isolated from mammary tissues with mastitis in cattle (Greig and Bannister 1965, Gourlay et al. 1974, Roberts et al. 1974).
BPIV-3 virus, a member of the Paramyxoviridae family, was isolated from Japanese cattle with nasal secretions and milk (Kawakami et al. 1966a). Furthermore, this virus was identified in milk of 14 of 58 cattle. Although the cattle which BPIV-3 virus was isolated from its milk did not observe any signs of clinical mastitis, somatic cell counts (SCCs) were increased in milk samples. Another study revealed that BPIV-3 virus was found in milk of cattle with typical aseptic mastitis (Kawakami et al. 1966b).

The Bovine Papilloma viruses (BPV) belong to the Papillomaviridae family (Olson 1990). BPV-1, BPV-2, and BPV-13 can infect and cause the development of tumors in cattle (Bocaneti et al. 2016). Different types of BPV have been identified into four genera, including Xipapillomavirus, Deltapapillomavirus, Epsilonpapillomavirus, and Dyoxipapillomavirus (Hamad et al. 2016, Lunardi et al. 2013). Since BPV can cause the fibropapillomas in the ductus papillaris, this virus could show a predisposition in cattle with mastitis (Francis 1984).

When literature review is conducted, it is revealed that there is not enough study which is performed on viral agents and mastitis/subclinical mastitis, and there is not enough information about the effect of viral agents on mastitis. From here, the aim of this study is to determine the presence and distribution of viral agents BPIV-3, BPV-1, BPV-2, and BHV-1, by using Immunofluorescence assay and qRT-PCR methods in the mammary tissue of cattle.

\section{MATERIAL and METHOD}

\section{Material}

The material of this study consisted of 120 mammary tissue samples (average 15 samples collected per week) obtained from slaughterhouses without any selection before slaughtering of animals in Erzurum Province in Turkey. Mammary tissue samples were collected randomly by using lancet without distinction or irrespective of whether it is inflammated or not to determine the presence of agents in cases of subclinical mastitis. Collected samples were brought to the laboratory for routine histopathology, Immunofluorescence assay, and total RNA isolation procedures.

\section{Routine Histopathology}

Each received mammary samples were stored for 1 day to be fixed in a $10 \%$ buffered formalin solution for histopathology and immunohistochemistry and half of each sample were stored $-20^{\circ} \mathrm{C}$ for PCR. The routine histopathological process was performed in Shandon Citadel 2000 (USA) tissue system. After the routine histopathology process, all samples were poured into paraffin for blocking and prepared microtome sections in $5 \mu \mathrm{m}$ by using rotary microtome (Leica RM 2255). All microtome sections 
were stained with hematoxylin-eosin (Presnell and Schreibman 1997).

\section{Immunofluorescence Staining Method}

After the routine histopathology process, $4 \mu \mathrm{m}$ of paraffin sections were taken on to lysine-coated slides. These slides put in the oven for deparaffinization in $57^{\circ} \mathrm{C}$ for 1 hour. For indirect immunofluorescence staining, paraffin sections in 4 $\mu \mathrm{m}$ were placed on lysine-coated slides after primary antibody (Bovine Parainfluenza Virus Type 3 antibody, aPI116J10, BioX, 1/250 dilution; AntiBovine Papilloma Virus E2 antibody, ab77174, abcam, 1/250 dilution; BoHV-1 antibody, aIBR16L12, BioX, 1/250 dilution) application which was performed according the same test protocol of immunohistochemistry, $1 \backslash 50$ diluted seconder immunofluorescence antibody (Cat No: Goat AntiRabbit IgG H\&L (FITC) dropped $12 \mu$ by using micropipette to each slide and waited 45 minutes in the darkness. After standing in the dark, slides were washed with distilled water and covered with mounting medium (glycerol, 9 volumes; PBS 1 volume). All slides were examined in florescence microscope (Carl Zeiss Axio Skop A1 with Calibri 2 led fluorescence attachment).

\section{Total RNA Isolation}

Total RNA isolation was realized from the collected mammary tissue samples through the utilization of Trizol (Invitrogen, USA). Total RNA isolation was realized in line with the manufacturer's protocol. Following the total RNA isolation, the RNA concentration was measured by virtue of NanoDrop (Epoch Microplate Spectrophotometer, USA). RNAs were run in a $1.5 \%$ agarose gel in $1 \mathrm{XTBE}$ solution for one hour at 80 volts with a view to control total RNA quality and visualized by gel the imaging system and their RNA quality was determined.

\section{DNase I treatment and cDNA Synthesis}

DNase I (Thermo Scientific, USA) was performed against DNA contamination in isolated RNA samples. DNase I treatment was performed in line with the protocol provided in the kit. Subsequently, 1 $\mu \mathrm{g}$ was taken from these RNAs and cDNA was synthesized through utilization of the miScript Reverse Transcription Kit (Qiagen, Germany) in line with the protocol provided. The purity and quantity of the obtained cDNA was measured by virtue of spectrophotometer (Epoch Microplate Spectrophotometer, USA), and the cDNAs were diluted at the same ratios. Subsequently, the cDNA samples were stored at $-20{ }^{\circ} \mathrm{C}$ for utilization in Real Time PCR studies.

\section{Real time PCR}

qRT-PCR was performed through utilization of the CFX96 BioRad device in order to detect BPIV-3, BHV-1, BPV-1, and BPV-2. The $\beta$-actin gene was employed for internal control. Master mix content created in real time PCR experiments is as follows: Syber Green 2X Rox Dye Master mix (Qiagen Germany), forward and reverse primers designed for genes, cDNAs as template and nuclease-free water. The samples were analyzed in Real-Time device following the preparation of master mixes. Reaction conditions and primer sequences of the genes are shown in Table 1. The primer sequences were received from previously conducted studies (Thonur et al. 2012, Pangty et al. 2010, Kubis et al. 2013).

\section{Statistical analysis}

IBM SPSS 20 program was performed for statistical analysis. The $\mathrm{Cp}$ values of each virus were evaluated using a linear mixed model (Thonur et al. 2012).

\section{RESULTS}

\section{Histopathological evaluation}

Histopathologic evaluation showed different character and severity of inflammatory changes in 78 of 120 cases. 56/120 samples were diagnosed with chronic subclinic mastitis and 22/120 cases were diagnosed with acute mastitis. In chronic subclinical cases, mononuclear cell infiltration in interstitial tissue and interalveolar septum thickness due to increased connective tissue were observed (Fig.1A, 1B). In acute cases, the presence of exudates containing neutrophil leukocytes in alveoli of mammary gland was observed. Degeneration and necrosis of alveolar epithelial layer, desquamation of gland epithelium were observed as common findings. Nonspecific chronic inflammatory cells such as lymphocyte and macrophage infiltrations (Fig. 1A, 1B, 1C) were detected in histopathological examination of BPIV-3 and BPV positive samples. Mononuclear cells accumulation, inclusion bodies in the cytoplasm of epithelial cells (Fig. 1C) were observed in BHV-1 positive tissues.

\section{Immunofluorescence staining results}

In the immunofluorescence staining, positive reactions for viral agents were observed in mammary gland epithelium, especially in mononuclear cells in the region (Figs. 1D, 1E, 1F). According to the results, the fluorescent positive reactions were detected in totally 50 cases with chronic (subclincal) mastitis (26/120 for BPIV-3, 8/120 for BPV-2 and $16 / 120$ for $\mathrm{BHV}-1)$.

\section{Integrity of material}

A $\beta$-actin signal was observed in all mammary samples tested in the qRT-qPCR indicating no evidence of extraction failure or PCR inhibition. (Fig.2)

\section{Real-Time PCR Results}

A ten-fold serial dilution of each of the in vitro transcribed RNAs of BPIV-3, BHV-1, BPV-1, and 
BPV-2 was triplicate analysis. The standard curves identified with qRT-PCR are shown in Figs. 3A, 3B, and $3 \mathrm{C}$. All four targets were analyzed simultaneously and no evidence of cross reactivity between primers was detected. BPIV-3 agent was detected by the qRTPCR in 26/120 samples, BHV-1 agent in 16/120 samples, BPV-1 agent in 7/120 samples, and BPV-2 agent in 8/120 samples. Coinfection with BPIV-3 and $\mathrm{BHV}-1$ was detected in 5/120 samples, BPIV-3, and BPV-1 in 3/120 samples, BHV-1 and BPV-1 in 2/120 samples (Table 2). BPIV-3, BHV-1, BPV-1, and BPV-2 nucleic acid signals were shown in Figs. $4 \mathrm{~A}, 4 \mathrm{~B}, 4 \mathrm{C}$, and 4D.

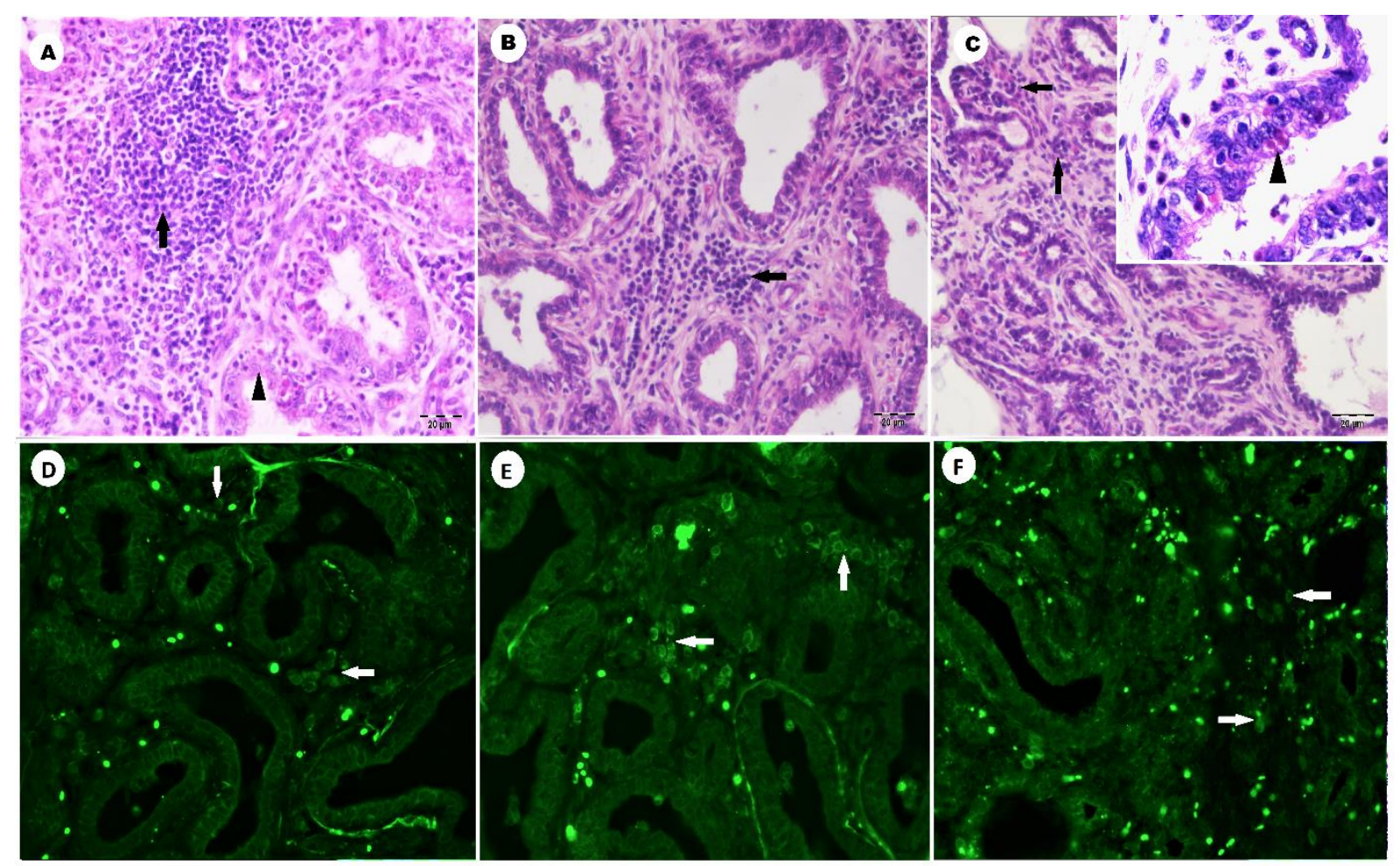

Figure 1. Histopathological and Immunofluorescence staining results A) Mononuclear cell infiltrations in the interstitial space (arrow), Degeneration and necrosis in the gland epithelium (arrowhead). BPIV-3. H \& E. $20 \mu \mathrm{m}$. B) Mononuclear cell infiltrations (arrow), BPV-1. H \& E. $20 \mu \mathrm{m}$. C) Plasma cell accumulation (arrows), intracytoplasmic eosinophilic inclusion bodies (arrowhead). BHV-1. H \& E. $20 \mu \mathrm{m}$. D) Positivity in mononuclear cells of BPIV-3 (arrows). IF. $20 \mu \mathrm{m} \mathrm{E}$ ) Positivity (arrows) in mononuclear cells of BPV-1 agent, IF. $20 \mu \mathrm{m}$. F) Positive reaction for BHV-1 agent (arrows) in mononuclear cells. IF. $20 \mu \mathrm{m}$.

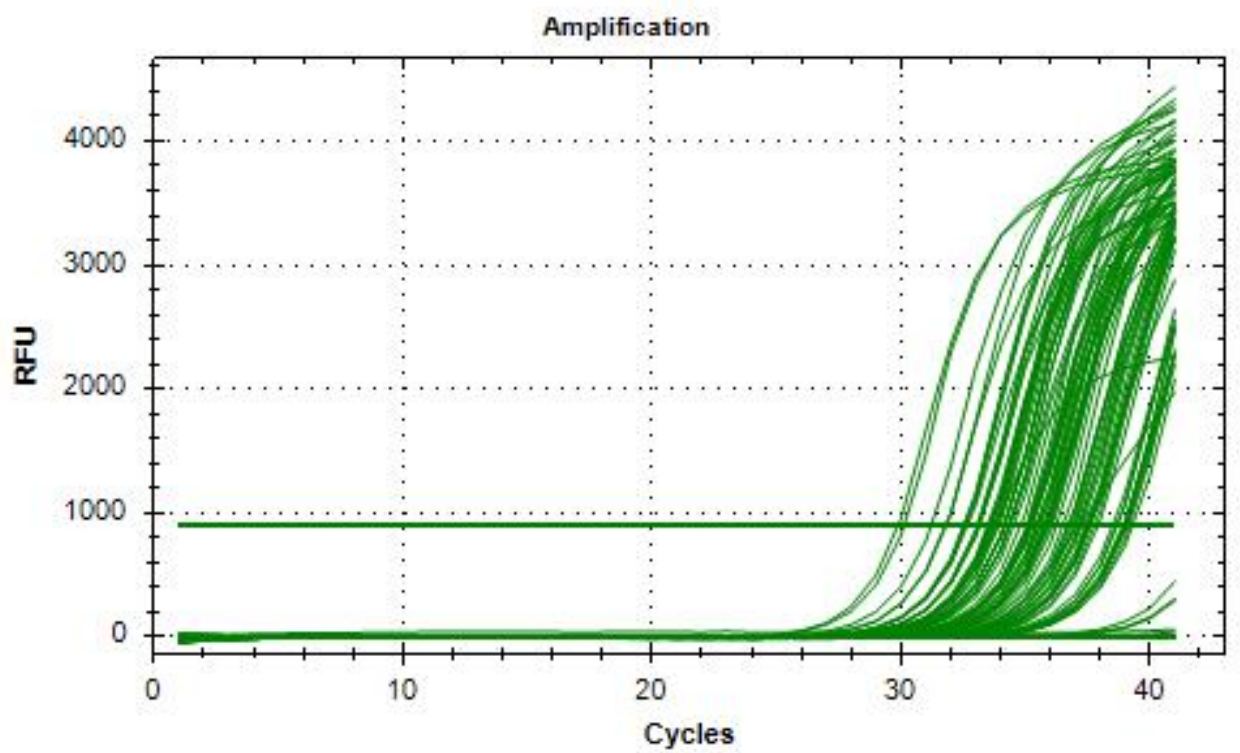

Figure 2. $\beta$-actin signals for all tissues 

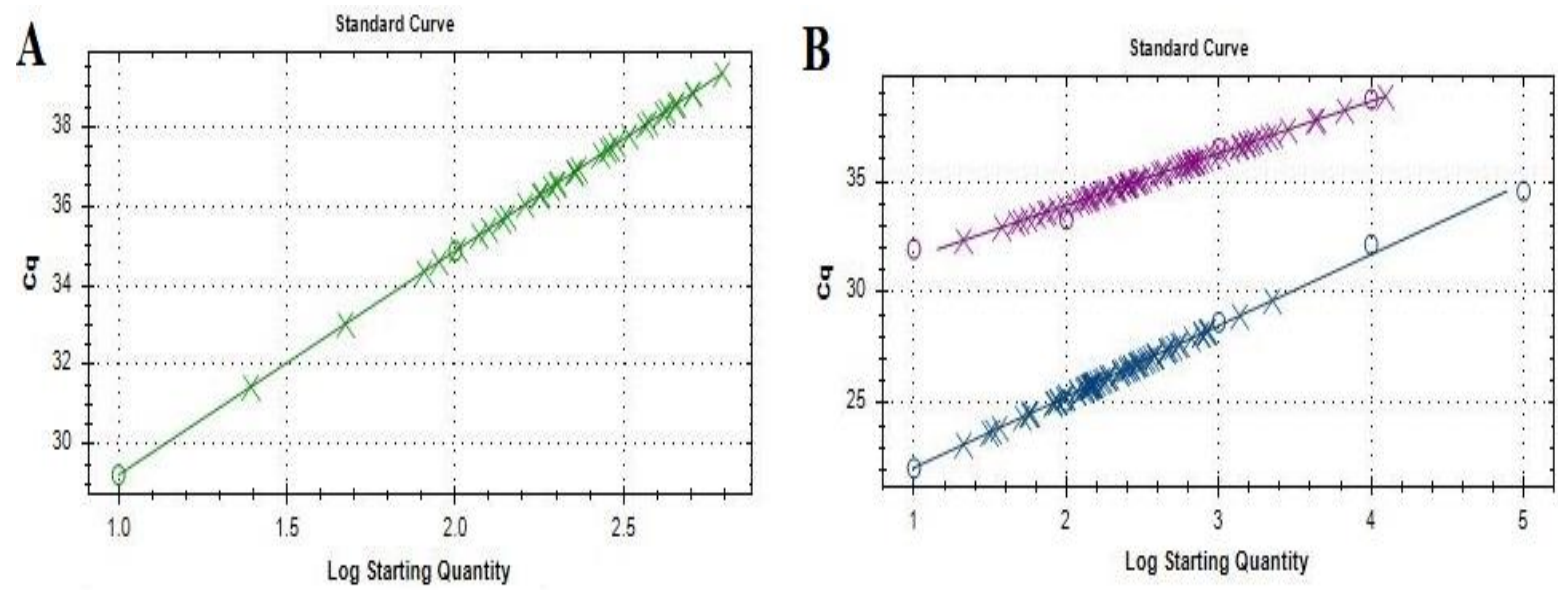

Figure 3. The standard curves for each virus. A) Standard curves of BPIV-3. B) Standard curves of BHV-1 and BPV-1 (purple; BHV-1, dark blue; BPV-1).

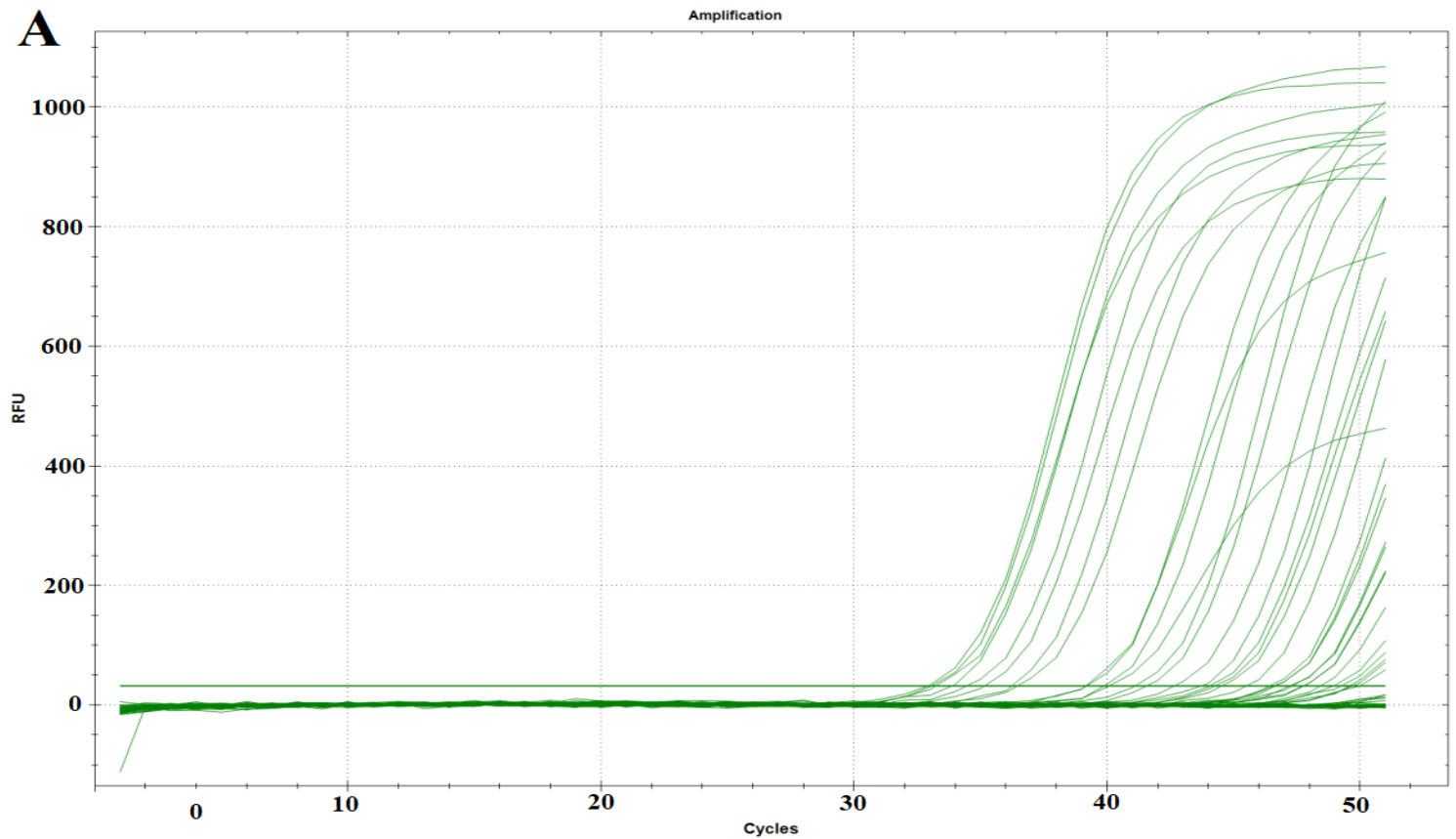

Figure 4. BPIV-3, BHV-1, BPV-1 and BPV-2 nucleic acid signals. A) BPIV-3.

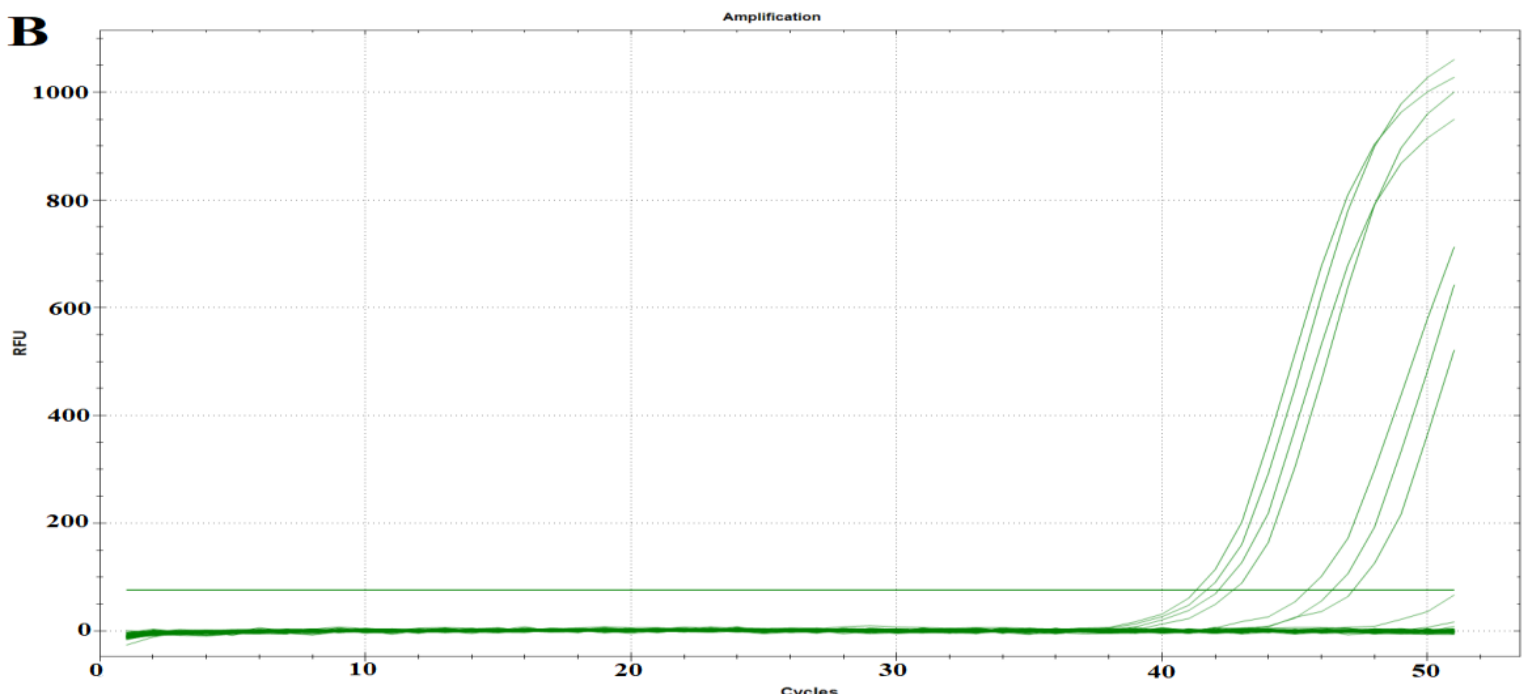

Figure 4. BPIV-3, BHV-1, BPV-1 and BPV-2 nucleic acid signals. B) BPV-1. 


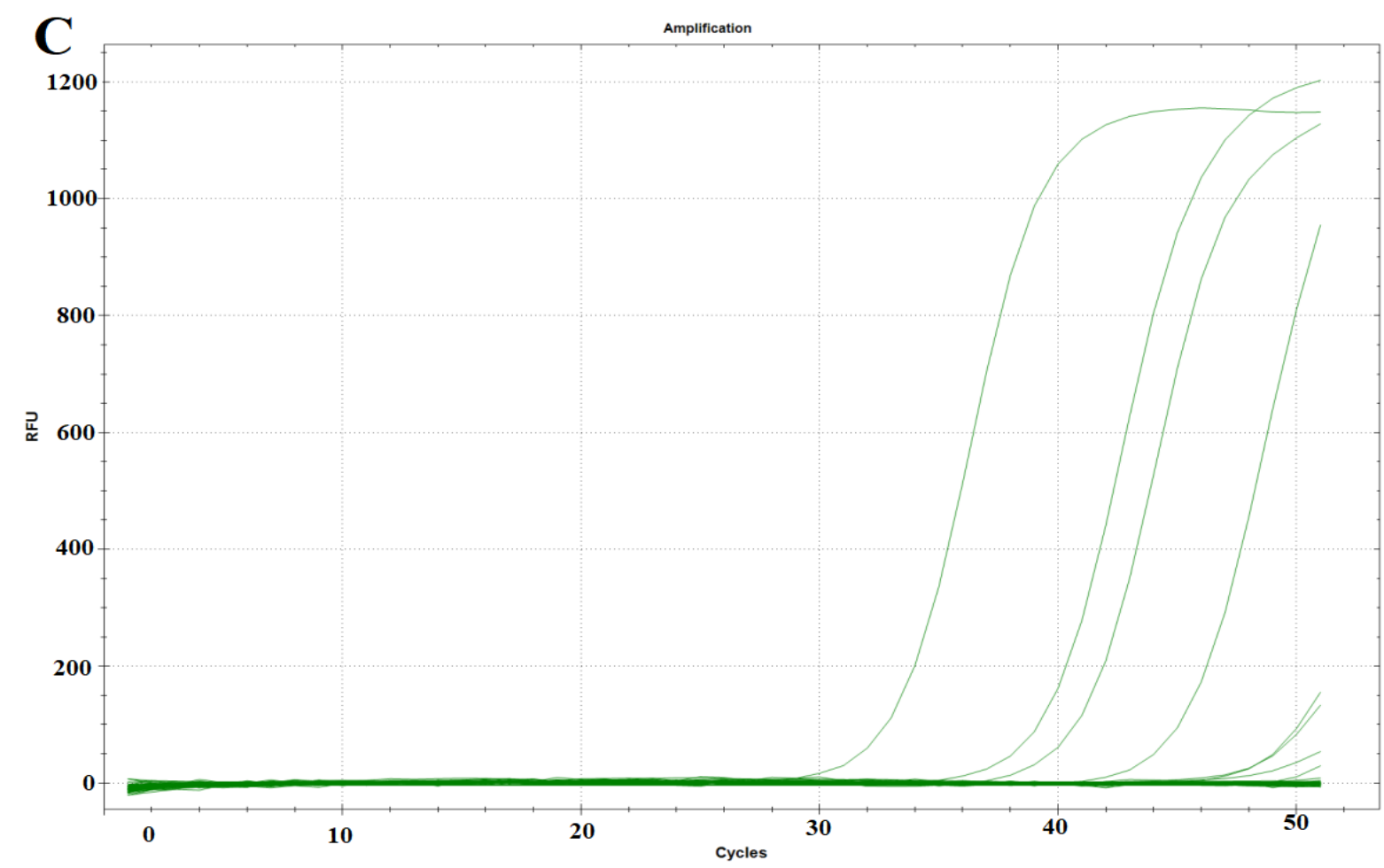

Figure 4. BPIV-3, BHV-1, BPV-1 and BPV-2 nucleic acid signals. C) BPV-2.

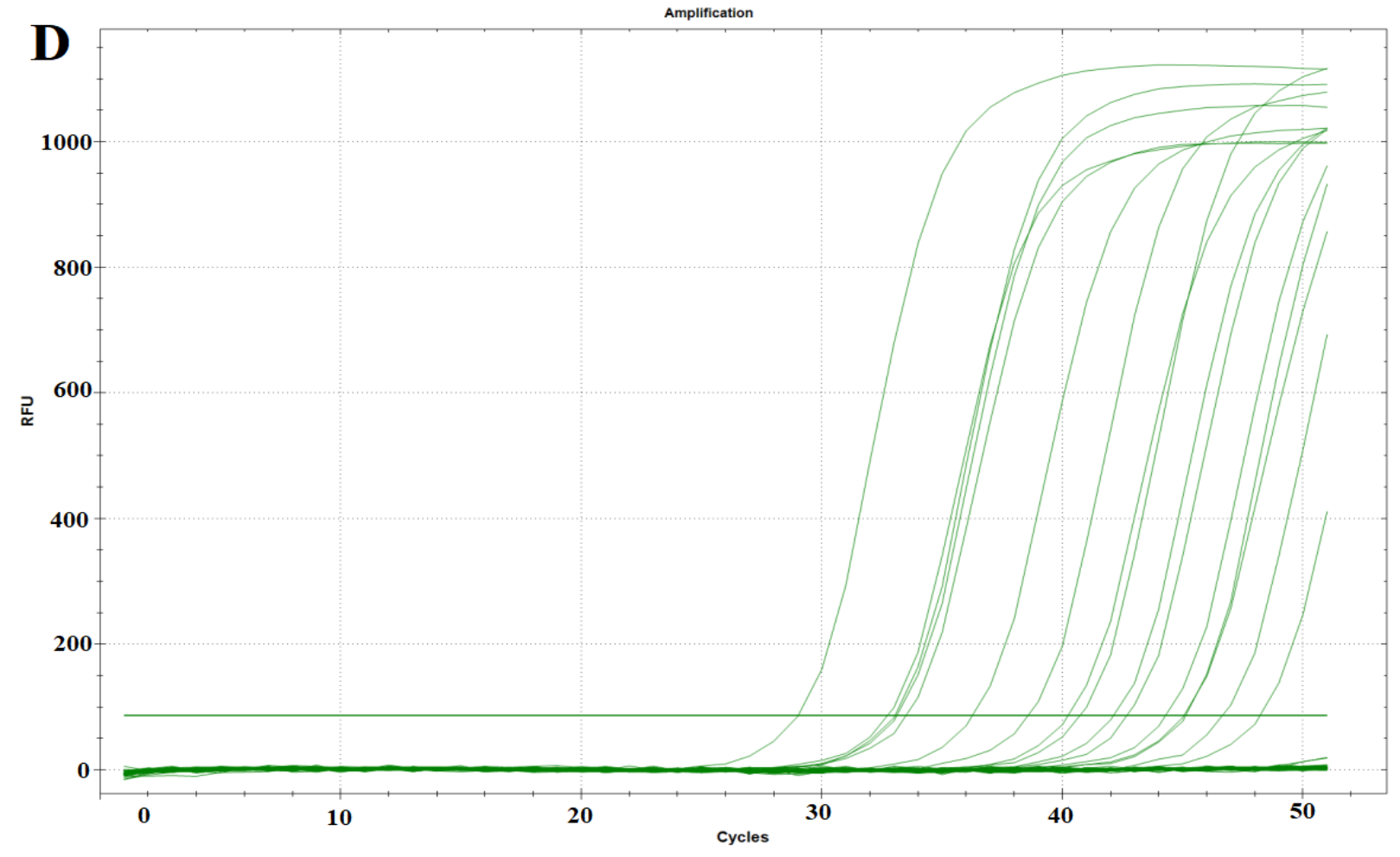

Figure 4. BPIV-3, BHV-1, BPV-1 and BPV-2 nucleic acid signals. D) BHV-1 
Table 1. Primer sequences of BPIV-3, $\beta$-actin, BPV-1, BPV-2, and BHV1

\begin{tabular}{|c|c|c|c|}
\hline $\begin{array}{l}\text { Gen } \\
\text { Name }\end{array}$ & Primer sequences & Reaction Conditions & References \\
\hline BPIV-3 & $\begin{array}{l}\text { F:TGATTGGATGTTCGGGAGTGA } \\
\text { R:AGAATCCTTTCCTCAATCCTGATATACT }\end{array}$ & $\begin{array}{l}94^{\circ} \mathrm{C} \text { for } 15 \mathrm{~s}, 58^{\circ} \mathrm{C} 30 \mathrm{~s} / 72^{\circ} \mathrm{C} 30 \mathrm{~s} . \\
(40 \text { cycle) }\end{array}$ & Thonur et al. 2012 \\
\hline$\beta$-actin & $\begin{array}{l}\text { F: GACAGGATGCAGAARGAGATCAC } \\
\text { R: TCCACATCTGCTGGAAGGTG }\end{array}$ & $\begin{array}{l}94^{\circ} \mathrm{C} \text { for } 15 \mathrm{~s}, 55^{\circ} \mathrm{C} 30 \mathrm{~s} / 72{ }^{\circ} \mathrm{C} 30 \mathrm{~s} . \\
(40 \text { cycle) }\end{array}$ & Thonur et al. 2012 \\
\hline BPV-1 & $\begin{array}{l}\text { F: GGA GCG CCT GCT AAC TAT AGG A } \\
\text { R: ATC TGT TGT TTG GGT GGT GAC }\end{array}$ & $\begin{array}{l}94^{\circ} \mathrm{C} \text { for } 15 \mathrm{~s}, 57^{\circ} \mathrm{C} 30 \mathrm{~s} / 72^{\circ} \mathrm{C} 30 \mathrm{~s} . \\
(40 \text { cycle })\end{array}$ & Pangty et al. 2010 \\
\hline BPV-2 & $\begin{array}{l}\text { F: GTT ATA CCA CCC AAA GAA GAC CCT } \\
\text { R: CTG GTT GCA ACA GCT CTC TTT CTC }\end{array}$ & $\begin{array}{l}94{ }^{\circ} \mathrm{C} \text { for } 15 \mathrm{~s}, 57^{\circ} \mathrm{C} 30 \mathrm{~s} / 72{ }^{\circ} \mathrm{C} 30 \mathrm{~s} . \\
(40 \text { cycle })\end{array}$ & Pangty et al. 2010 \\
\hline BHV-1 & $\begin{array}{l}\text { F: TGTGGACCTAAACCTCACGGT } \\
\text { R: GTAGTCGAGCAGACCCGTGTC }\end{array}$ & $\begin{array}{l}94^{\circ} \mathrm{C} \text { for } 15 \mathrm{~s}, 59^{\circ} \mathrm{C} 30 \mathrm{~s} / 72{ }^{\circ} \mathrm{C} 30 \mathrm{~s} . \\
(40 \text { cycle })\end{array}$ & Thonur et al. 2012 \\
\hline
\end{tabular}

Table 2. Real time RT-PCR results for 120 samples

\begin{tabular}{lccccccc}
\hline Material & BPIV-3 & BHV-1 & BPV-1 & BPV-2 & $\begin{array}{l}\text { BPIV-3 and } \\
\text { BHV-1 }\end{array}$ & $\begin{array}{l}\text { BPIV-3 and } \\
\text { BPV-1 }\end{array}$ & $\begin{array}{l}\text { BHV-1 and } \\
\text { BPV-1 }\end{array}$ \\
\hline $\begin{array}{l}\text { Mammary } \\
\text { tissue }\end{array}$ & 26 & 16 & 7 & 8 & 5 & 3 & 2 \\
$\begin{array}{l}\text { Percentage } \\
(\%)\end{array}$ & $21.6 \%$ & $13.3 \%$ & $5.8 \%$ & $6.6 \%$ & $4.16 \%$ & $2.5 \%$ & $1.6 \%$ \\
\hline
\end{tabular}

\section{DISCUSSION}

Bovine mastitis disease causes important economic losses all over the World. Although, the number of studies on the presence and role of viral agents in mastitis cases is very low. BPIV-3, BHV-1, BPV-1, and BPV-2 are the most important agents among viral pathogens shown to be responsible for mastitis cases. Besides the severity of disease increases by various factors like stress, environmental conditions, immunodeficiency (Wellenberg et al. 2002, Underwood WJ et al. 2015).

Mastitis cases are among the common herd health problems in our country as in all over the world. Mastitis has been reported to occur in many mammalian species, especially in domestic dairy cows (Petrovski et al. 2006, Gomes and Henriques 2016). In the previous studies, the presence and the role of bacterial agents in mastitis cases are emphasized (Bogni et al. 2011, Gomes and Henriques 2016). However, no detailed studies have been found in the presence of viral agents that play an important role in diseases such as other respiratory system diseases.

Foot and Mouth Disease Virus (FMDV), Bovine Herpesvirus 4 (BHV-4), Bovine Herpesvirus 2 (BHV2), cattle Pox Virus, Bovine Viral Diarrhea Virus (BVDV), Vesicular Stomatitis, Bovine Herpes Virus 1 (IBR / IPV), Bovine Herpesvirus-3 (BHV-3), Coryza Gangrenosa Bovum (CGB), Bovine Enterovirus (BEV), Bovine Parainfluenza 3 (BPIV-3), Bovine leukosis were reported as examples of viral infections that cause mastitis in cattle or that are involved in mastitis (Molen et al. 1985, Reid et al. 2006). In our country, except for some seroprevalence reports (Alkan et al. 1997, Yesilbag and Güngör 2008), no study was found in this scope.

In the previous study by Kawakami et al. (1966a), BPIV-3 was detected in the nasal fluid of Japanese cows with respiratory diseases and milk and mammary tissues of mastitis cows. In cases of mastitis caused by BPIV-3, there is fever and weight loss in cows. In addition, BPIV-3 is seen in both clinical and subclinical mastitis (Kawakami et al. 1966b, Wellenberg et al. 2002). In the studies, it has been shown that this virus causes mastitis in the cows with the bactericidal factors that cause mastitis (William et al. 1992, Wellenberg et al. 2002).

BHV-1 usually infects mammary tissue in young cows during the first lactation period. This infection may be sub-clinical or clinical. BHV-1 infections are particularly damaging to the ductus papillaris and sinus lectoris (Senft and Neudecker 1991). This situation makes the mastitis cases caused by bacteria more harmful. BHV-1 can be found in the milk of cows with mastitis (Wellenberg et al. 2002, Kubis et al. 2013). Intramammary inoculation of BHV-1 induce the signs of clinical mastitis. Besides, a significant decrease in milk production was recorded, and milk samples showed intense consistency after the intramammary inoculation of cows with the BHV-1 (Greig and Bannister 1965).

In an experimental study based on an outbreak of BHV-1 for 98 lactating animals was induced by injecting three seropositive cows with dexamethasone. They have reported that a significant decrease in milk production in initially-seronegative 
cows that became infected but not in seropositive cows (Hage JJ et al. 1998)

Turner et al. (1976) reported that they isolated BHV2 from vesicular fluid and swab samples from the mammary of 31 dairy cows. In herpes mammillitis cases in Canada, it was determined that the samples collected from the lesions were determined by virus isolation and electron microscopy and mastitis rate increased in the herd. As a result, BHV-2 infections are thought to increase the sensitivity of the mammary due to damage to the natural defense mechanism and to increase the sensitivity to bacterial infections (Martin et al. 1987).

In the present study, BPIV-3 agent was detected by the qRT-PCR in 26/120 samples, BHV-1 agent in 16/120 samples, BPV-1 agent in 7/120 samples, and BPV-2 agent in 8/120 samples. Coinfection with BPIV-3 and BHV-1 was detected in 5/120 samples, BPIV-3, and BPV-1 in 3/120 samples, BHV-1 and BPV-1 in 2/120 samples. Degeneration and necrosis of alveolar epithelial layer, desquamation of gland epithelium were observed as common findings. Nonspecific chronic inflammatory cells such as lymphocyte and macrophage infiltrations were detected in histopathological examination of BPIV-3 and BPV positive samples. infiltration of mononuclear cells, inclusion bodies in the cytoplasm of epithelial cells were observed in BHV-1 positive tissues. In the immunofluorescence staining, positive reactions for viral agents were observed in mammary gland epithelium, especially in mononuclear cells in the region. According to the results, the fluorescent positive reactions were detected 26/120 for BPIV-3, 16/120 for BHV-1 and 8/120 for BPV-2.

In accordance with the information in the literature, similar to the findings of nonspecific histopathological examinations observed in other tissues and organs infected with viral agents, histopathological examination of the mammary tissues revealed no specific findings other than the infiltration of chronic inflammatory cell formation. Especially the subclinical form of mastitis is high in clinical mastitis form, subclinical mastitis cannot be noticed by the breeders, the disease is a herd problem, the disease resistance to drug treatment reveals the importance of the disease (Sharma et al. 2006, Sandev et al. 2004).

According the literature, viruses induce reduction of the natural defense mechanisms of the udder and immune system deficiency like by causing teat lesions (Francis 1984, Wellenberg et al. 2002, Underwood WJ et al. 2015). Our results demonstrate that BPIV-3, BPV, and BHV-1 neither cause mastitis directly nor play a pivotal role in clinical mastitis, because of isolation of bacterial agent was not performed. But obtained findings like intracytoplasmic inclusion bodies in epithelial cells enfected with BHV-1 and positive immune signs of viral agents in the cytoplasm of the inflammatory cells in mammary tissues, made us think that viral agents may be responsible for clinical mastitis turn into subclinical mastitis or prolonged the inflammation after or before of the bacterial infection of the mammary glands occurred.

\section{CONCLUSION}

In conclusion, our findings demonstrate a high prevalence of viral agents in cattle mammary tissue in the east of Turkey. Suitable environment conditions for the animals waiting to be able to create an infectious disease in the normal flora and subclinical infected cows of the factors shows that the continuity of this threat. There is a critical need for preventative strategies in the farm for viral pathogens like rapid elimination of subclinically virus carrier animals from herd via periodically screening for viral disease in terms of subclinical mastitis.

\section{ACKNOWLEDGEMENT}

This study was supported by the Scientific Research Projects Coordination Unit of Atatürk University (PRJ2016 / 87)

\section{REFERENCES}

Alkan F, Ozkul A, Karaoğlu MT, Bilge S, Akça Y, Burgu I, Yesilbag K, Oguzoglu TC. Sığırlarda viral nedenli solunum sistemi enfeksiyonlarının epidemiyolojisi. Ankara Univ. Vet. Fak. Derg. 1997; 44: 1-8.

Bilge S. Detection of antibodies of IBR-IPV infection in blood and milk by serum neutralization test and virus isolation from milk samples in dairy cows. Ankara Univ. Vet. Fak. Derg. 1998; 45: 313-321.

Bocaneti F, Altamura G, Corteggio A, Velescu E, Roperto F, Borzacchiello G. Bovine papillomavirus: New insights into an old disease. Transbound Emerg Dis. 2016; 63(1): $14-23$.

Bogni C, Odierno L, Raspanti C, Giraudo J, Larriestra A, Reinoso, E, Lasagno M, Ferrari M, Ducro's E, Frigerio C, Bettera S, Pellegrino, M, Frola I, Dieser S, Vissio C. War against mastitis: current concepts on controlling bovine mastitis Pathogens. In: Me'ndez-Vilas A (ed) Science against microbial pathogens: communicating current research and technological advances. World Scientific, Singapore. 2011; 483-494.

Espinasse J, Gilbert Y, Saurat P. Features of bovine rhinotracheitis in a dairy herd in south-western France. Rev. Med. Vet. 1974; 125: 1441-1452.

Francis PG. Teat skin lesions and mastitis. Br. Vet. J. 1984; 140: 430-436.

Gomes F, Henriques M. Control of Bovine Mastitis: Old and Recent Therapeutic Approaches", Curr Microbiol. 2016;72(4): 377-82.

Gourlay RN, Stott EJ, Espinasse J, Barle C. Isolation of Mycoplasma agalactiae var. bovis and infectious bovine rhinotracheitis virus from an outbreak of mastitis in France. Vet. Rec. 1974; 95: 534-535. 
Greig AS, Bannister GL. Infection of the bovine udder with bovine herpesvirus. Can. J. Comp. Med. Vet. Sci. 1965; 29: pp. 57-62.

Hage JJ, Schukkenb YH, Dijkstraa TH, Barkemaa HW, van Valkengoedb PHR, Wentink GH. Milk production and reproduction during a subclinical bovine herpesvirus 1 infection on a dairy farm. Prev Vet Med. 1998; 34: 97-106.

Hamad MA, Al-Shammari AM, Odisho SM, Yaseen NY. Molecular and Phylogenetic Analysis of Bovine Papillomavirus Type 1: First Report in Iraqi Cattle. Adv Virol. 2016; 2143024.

Kálmán D, Jánosi S, Egyed L. Role of bovine herpesvirus 4 in bacterial bovine mastitis. Microb Pathog. 2004; 37: 125129.

Kawakami Y, Kaji T, Kume T, Omuro M, Hiramune T, Murase N, Matumoto M. Infection of cattle with parainfluenza 3 virus with special reference to udder infection. I. Virus isolation from milk. Jpn. J. Microbiol. 1966a; 10: 159-169.

Kawakami Y, Kaji T, Omuro M, Maruyama Y, Hiramune T, Murase N, Matumoto M. Infection of cattle with parainfluenza 3 virus with special reference to udder infection. II. Pathology of the virus to cattle, with particular reference to the mammary gland. Jpn. J. Microbiol. 1966b; 10: 171-182.

Kubis P, Materniak M, Kuzmak J. Comparison of nested PCR and qPCR for the detection and quantitation of BoHV6 DNA. J Virol Methods. 2013; 194: 94-101.

Lunardi M, Alfieri AA, Otonel RAA, de Alcântara BK, Rodrigues WB, de Miranda AB. Genetic characterisation of a novel bovine papillomavirus member of the Deltapapillomavirus genus. Vet Microbiol. 2013; 162(1): 207-213.

Martin JR, Harvey D, Montpetit C. Bovine herpetic mammillitis in Quebec. Can Vet. J. 1987; 28: 529-523.

Molen EJ, Vecht U, Houwers DJ. A chronic indurative mastitis in sheep, associated with maedi/visna virus infection. Vet Q. 1985; 7:(2) 112-119.

Olson C. Papillomaviruses. In: Dinter, Z., Morein, B. (Eds.), Virus Infections of Ruminants. Elsevier, Amsterdam. 1990; 189-200.

Pangty K, Singh S, Goswami R, Saikumar G, Somvanshi R. Detection of BPV-1 and -2 and Quantification of BPV-1 by Real-Time PCR in Cutaneous Warts in Cattle and Buffaloes. Transbound Emerg Dis. 2010; 57: 185-196.

Petrovski KR, Trajcev M, Buneski G. A review of the factors affecting the costs of bovine mastitis", J South Afr Vet Assoc. 2006; 77: 52-60.

Presnell J, Schreibman MP. Animal Tissue Techniques. 5th ed. London. The Johns Hopkins University Press Ltd, 1997; 269-271.

Reid SM, Parida S, King DP, Hutchings GH, Shaw AE, Ferris NP, Zhang Z, Hillerton JE, Paton DJ. Utility of automated real-time RT-PCR for the detection of footand-mouth disease virus excreted in milk. Vet Res. 2006; 37: 121-32.

Roberts AW, Carter GR, Carter FA. Infectious bovine rhinotracheitis virus recovered from milk of a cow with mastitis. J. Am. Vet. Med. Assoc. 1974; 164: 413.

Sandev N, Koleva M, Binev R, Ilieva D. Influence of enzootic leukosis virus upon the incidence of subclinical mastitis in cows at a different stage of infection. Vet. Arhiv. 2004; 74: 411-416.

Senft B, Neudecker J. Abwehrmechanismen der bovinen Milchdru"se. Tiera"rztl. Praxis. 1991; 19: 357-363.

Siegler HH, Marschang F, Morscher H. Beobachtungen u"ber Zusammenha"nge zwischen Virusinfectionen und boviner Mastitis. Tiera"rztl. Umschau. 1984; 39: 602-604.

Sharma A, Dhingra P, Pander BL, Kumar R. Bovine subclinical mastitis: prevalence and treatment with homeopathic medicine. Intl. J. Cow Sci. 2006; 2: 40-44.

Turner AJ, Morgan IR, Sykes WE, Nicholls WA. Bovine herpes mammillitis of dairy cattle in Victoria. Aust Vet J. 1976 Apr; 52(4):170-3.

Thonur L, Maley M, Gilray J, Crook T, Laming E, Turnbull $\mathbf{D}$, Nath M, Willoughby $\mathbf{K}$. One-step multiplex real time RT-PCR for the detection of bovine respiratory syncytial virus, bovine herpesvirus 1 and bovine parainfluenza virus 3. BMC Vet Res. 2012; 8: 37.

Underwood WJ, Blauwiekel R, Schoell A. Biology and Diseases of Ruminants (Sheep, Goats, and Cattle), In: Laboratory Animal Medicine. Third Edition, 2015 Elsevier Inc. 2015; pp. 623-694.

Yesilbag K, Güngör B. Seroprevalance of bovine respiratoty viruse in orth-Western Turkey. Trop. Anim. Health. Prod. 2008; 40: 55-60.

Wellenberg GJ, van der Poelb WHM, Van Oirschota JT. Viral infections and bovine mastitis: a review. Vet Microbiol. 2002; 88: 27-45.

William JB, Kirubaharan JJ, Uthuman KM, Kumanan K, Balachandran S. Survey on incidence and complications of bovine cutaneous papillomatosis. Indian Vet. J. 1992; 69: 843-844. 